\title{
Based on historical seismic damage data to rapidly assessment the vulnerability of structures in rural village
}

\author{
Xinqiang Yao, Bin Liang ${ }^{\mathrm{b} *}$, Baitao Sun ${ }^{\mathrm{c}}$ and Wuping Gao \\ a Tianjin Earthquake Agency, Tianjin 300202, China. \\ b College of Civil Engineering, Dalian University of Technology, Dalian 116033, China. \\ c Institute of Engineering Mechanics, China Earthquake Administration, Harbin 150080, China \\ * Correspondence: Liang-Bin@mail.dlut.edu.cn.
}

\begin{abstract}
This study investigated and classified typical structures in rural village and analyzed the vulnerability of various typical types of structures. Based on the statistics of earthquake damages with magnitudes above 5 from 1996 to 2013 in China, the damage matrixes of different types of structures in rural village are obtained. And The vulnerability index and the vulnerability equation of structure are crucial to assess the earthquake losses of typical structures under different magnitudes earthquakes. According to the seismic loss of different types of structures under different earthquake magnitudes, there are possible to improve the seismic resilience of the buildings in rural village. Moreover, the regional vulnerability is analyzed by $\beta$ probability distribution function, and the comprehensive seismic performance index of different types of agricultural buildings in the region is obtained. The main research is to predict the loss of different types of structures under different earthquake magnitudes in the future, and to provide technical support for different types of building in rural village reinforcement.
\end{abstract}

Keywords: rural village; earthquake; vulnerability index; vulnerability analysis; damage matrix

\section{Introduction}

In developing countries, the seismic resistance capabilities of buildings in rural villages are weak. Under the same earthquake intensity, the casualties and the buildings collapse in rural areas are more serious than those in cities (Yao, 2017). The developing countries have large numbers of structures in rural village (Polat \& Randolph, 2004, Güçhan, 2007). Due to the weak seismic resistance capacity of large number of buildings in rural villages of developing countries, the seismic performance of rural buildings can reflect the seismic capacity of a region or a country (Yao, 2019, Yao, 2017). From 2005, China accelerated the construction of structures in rural area. According to the statistical results in 2005, there were 61963 new rural buildings were built in China, accounting for $2.27 \%$ of total buildings in China (Yao, 2020). It can be seen that the buildings in rural area of China is constantly increasing (Yao, 2018). The key method to prevention and reduction loss is enhancing the seismic resistance capabilities of rural buildings in China and other developing countries. The research has great significance for improving rural buildings seismic capabilities in developing countries.

It is reasonable to choose the analysis method of structure seismic vulnerability method, which is the key to accurately assess the earthquake vulnerability of buildings in rural villages. There are the VI method has been used worldwide (Kenneth et al., 2008, Lourenco \& Roque, 2006, Lourenco et al., 2013), to elaborate seismic scenarios at large scale as in RISK-UE approaches (Milutinovic \& Trendafiloski, 2003), Hazard - United States (HAZUS) (National 
Institute of Building Sciences, 1997) and Risk Assessment Tools for Diagnosis of Urban Areas against Seismic Disaster (RADIUS) (OYO, 1999) methodologies. The seismic vulnerability of different types of structures in Algerian cities is analyzed by Delphi method, and the vulnerability of masonry structure is highlighted by empirical analysis (Yousfi, 2018). Moreover, Votsis et al. (2012) analyzed the seismic vulnerability of different types of buildings in Cyprus city by SAP2000. Whether it is empirical analysis or finite meta-analysis, the seismic vulnerability of building structures can be given. Romis et al. (2021) used the building structure vulnerability index to evaluate the seismic structural vulnerability. However, both types of vulnerability analysis methods require a lot of time and cannot meet the needs of a wide range of buildings in rural villages vulnerability analysis. Therefore, it is very necessary to establish a rapid analysis method of building vulnerability.

The method of vulnerability analysis should be based on the seismic damage state of different type of structures in historical earthquakes. Şahin et al. (2007) analyzed the 1894-Istanbul, 1970-Gediz and 1999-Kocaeli earthquake damage in Turkey, and discussed the seismic damage scenarios of different building structures. Vettore et al. (2020). The regional seismic disaster matrix is established and presented in GIS through the analysis of building vulnerability. Preciado et al. (2020) provides different seismic damage scenarios by associating building vulnerability levels and expected seismic damage levels with seismic intensity. Li et al. (2020) based on the seismic damage data to establish the empirical seismic damage probability matrix, the average susceptibility seismic index probability matrix model considering the probability of empirical earthquake vulnerability in multi-seismic areas is proposed. Gautam et al. (2016) studied a detailed field survey of Nepal's major world earthquake paradigm and historical earthquakes, as well as the Gurkha earthquake, is fully considered, explaining the lessons Nepal will learn from the Gurkha earthquake. A retrospective study of the seismic damage data of historical buildings is carried out to provide data support for the rapid analysis of the vulnerability of building structures.

In this paper, the historical disaster data are reviewed and the earthquake disaster matrix is established. Based on the seismic site survey data (Lourenço, 2002), five states of structural damage were determined: Intact, Minor, Medium, Serious, and Collapse (Pakdamar and Lourenço, 2019). Based on the rapid analysis method of building earthquake vulnerability, the historical seismic disaster data are studied retrospectively and the historical earthquake disaster matrix is established. Therefore, the comprehensive seismic vulnerability index of different types of building structures is obtained.

\section{Background and analysis method}

\subsection{Evaluation standard classification of earthquake damage level of rural structures}

According to the historical earthquake damage data, it is necessary to divide the seismic damage state level of the structures. The rule of dividing the seismic damage based on the damage state of the load-bearing components and non-load-bearing components of the structures and the difficulty of fixing the damage. According to the "Outline and Technical Guidelines for Earthquake Site Work" (China Earthquake Administration, 1998) and "Chinese building damage grade classification standards", the earthquake damage states can be divided into 5 grades (eg. intact, minor, moderate, and serious and collapse). The standard describes in detail the damage states of different types of structure.

The mentioned classification of earthquake damage levels is used to classification of typical structures, especially the classification standards of earthquake damage levels adopted for structures designed with codes. 
However, most of the rural residential structures have not been designed or constructed with the national code. Therefore, the seismic damages are quite different from those designed in accordance with the specifications.

Based on the detailed analysis and investigation of large of seismic damage data, the seismic damage of six types of structures is analyzed in rural village. According to the vulnerability of the components and locations, the seismic damage levels are divided in detail. The reinforced concrete members, walls, and roof systems play a key role for brick-concrete masonry structures to earthquake resistance (see Table 1). The classification standard for the earthquake damage level of brick-timbered masonry structures, mainly referring to the damage of brick walls, ring beams, structural columns, and roof systems to comprehensively classify the damage grades of the structure (see Table 2). Table 3 shows the detail seismic damage state of adobe and stone-wood structures. The walls are made of adobe or rammed earth walls and stone. The other components are basically the same. Therefore, Table 3 classifies the damage classification standards of the two types of structures into one category. In adobe structures and stone-wood structures, walls, wood columns and roof systems are the main factors for the classification of structural damage grades. The standard for classification of damage grades for wooden structures is to the damage of wooden columns and connectors and roof systems (see Table 4).

Table 1. Classification of damage grades of brick-concrete structure.

\begin{tabular}{|c|c|c|c|c|}
\hline Damage level & Concrete elements & Brick wall & Brick column & Roof \\
\hline Intact & $\begin{array}{l}\text { There is no looseness or cracks at } \\
\text { the overlap between the } \\
\text { reinforced concrete components } \\
\text { and the wall. The structural } \\
\text { columns and ring beams are } \\
\text { intact. }\end{array}$ & $\begin{array}{l}\text { The load-bearing walls are } \\
\text { intact, with small cracks in } \\
\text { some cases: some small } \\
\text { diagonal cracks in the corners } \\
\text { of the doors and windows. }\end{array}$ & $\begin{array}{l}\text { The brick pillars are } \\
\text { intact, with small cracks } \\
\text { in some cases. }\end{array}$ & $\begin{array}{l}\text { The roof is intact } \\
\text { with some tiny } \\
\text { cracks. }\end{array}$ \\
\hline Minor & $\begin{array}{l}\text { There are loose or slight cracks at } \\
\text { the lap joints of reinforced } \\
\text { concrete components and walls or } \\
\text { at the nodes of reinforced concrete } \\
\text { components. The structural } \\
\text { columns and ring beams are } \\
\text { intact. }\end{array}$ & $\begin{array}{l}\text { There are looseness and slight } \\
\text { cracks at the corners of the wall } \\
\text { and the junction of the vertical } \\
\text { and horizontal walls and } \\
\text { obvious cracks in } \\
\text { non-load-bearing walls such as } \\
\text { roof chimneys and parapets; } \\
\text { slight cracks in gables or door } \\
\text { and window openings. }\end{array}$ & $\begin{array}{l}\text { The brick columns are } \\
\text { intact. Part of it has slight } \\
\text { cracks. }\end{array}$ & $\begin{array}{l}\text { The roofs are } \\
\text { slightly cracked } \\
\text { and have no } \\
\text { obvious } \\
\text { deformation. }\end{array}$ \\
\hline Moderate & $\begin{array}{l}\text { There are obvious loosening and } \\
\text { obvious cracks at the joints of } \\
\text { reinforced concrete components } \\
\text { or the junction with the wall, and } \\
\text { some ring beams and structural } \\
\text { columns are slightly cracked. }\end{array}$ & $\begin{array}{l}\text { Some load-bearing walls have } \\
\text { obvious cracks; some } \\
\text { non-load-bearing walls such as } \\
\text { parapets have serious cracks or } \\
\text { partial cracks. }\end{array}$ & $\begin{array}{l}\text { The brick columns have } \\
\text { horizontal through } \\
\text { seams. }\end{array}$ & $\begin{array}{l}\text { There are obvious } \\
\text { cracks in the roof; } \\
\text { there are many } \\
\text { cracks in } \\
\text { individual roof } \\
\text { components. }\end{array}$ \\
\hline Serious & $\begin{array}{l}\text { Some reinforced concrete } \\
\text { components are damaged or } \\
\text { collapsed; structural columns and } \\
\text { ring beams have obvious cracks. }\end{array}$ & $\begin{array}{l}\text { The load-bearing wall appeared } \\
\text { serious cracks or even tilted, } \\
\text { and the non-load-bearing wall } \\
\text { collapsed. }\end{array}$ & $\begin{array}{l}\text { The brick pillars are } \\
\text { broken or most of them } \\
\text { are obviously damaged or } \\
\text { some are severely } \\
\text { cracked. }\end{array}$ & $\begin{array}{c}\text { There are } \\
\text { widespread cracks } \\
\text { in the roof, some } \\
\text { serious cracks and } \\
\text { even partial } \\
\text { collapse. }\end{array}$ \\
\hline Collapse & $\begin{array}{l}\text { Part of the reinforced concrete } \\
\text { components collapsed and no } \\
\text { possibility of repair. }\end{array}$ & Load-bearing walls collapsed. & $\begin{array}{l}\text { Most of the brick columns } \\
\text { were broken or collapsed. }\end{array}$ & $\begin{array}{l}\text { The roof is } \\
\text { severely cracked } \\
\text { and even } \\
\text { collapsed. }\end{array}$ \\
\hline
\end{tabular}


Table 2. Grade division of damage degree of brick-timber structural components.

\begin{tabular}{|c|c|c|c|}
\hline Damage level & Brick wall & Beam and column & Roof \\
\hline Intact & $\begin{array}{l}\text { The load-bearing walls are intact, with } \\
\text { small cracks in some cases: there are small } \\
\text { diagonal cracks in the corners of the doors } \\
\text { and windows. }\end{array}$ & $\begin{array}{l}\text { The ring beam and structural } \\
\text { column are intact. }\end{array}$ & $\begin{array}{l}\text { The roof is intact with some tiny } \\
\text { cracks. }\end{array}$ \\
\hline Minor & $\begin{array}{l}\text { There are loose and slight cracks at the } \\
\text { corners of the wall and the junction of } \\
\text { vertical and horizontal walls; obvious } \\
\text { cracks in non-load-bearing walls, roof } \\
\text { chimneys, and parapets; slight cracks in } \\
\text { gables or door and window openings. }\end{array}$ & $\begin{array}{l}\text { The ring beam and the wall are } \\
\text { loose or slightly cracked, and } \\
\text { the ring beam and structural } \\
\text { column are intact. }\end{array}$ & $\begin{array}{l}\text { The roof is slightly cracked and } \\
\text { has no obvious deformation. }\end{array}$ \\
\hline Moderate & $\begin{array}{l}\text { Some load-bearing walls have obvious } \\
\text { cracks; some non-load-bearing walls and } \\
\text { parapets are severely cracked or partially } \\
\text { broken. }\end{array}$ & $\begin{array}{l}\text { Some ring beams and structural } \\
\text { columns have obvious cracks. }\end{array}$ & $\begin{array}{l}\text { There are obvious cracks in the } \\
\text { roof; there are many cracks in } \\
\text { individual roof components. }\end{array}$ \\
\hline Serious & $\begin{array}{l}\text { The load-bearing wall appeared serious } \\
\text { cracks or even tilted, and the } \\
\text { non-load-bearing wall collapsed. }\end{array}$ & $\begin{array}{l}\text { There are obvious cracks in } \\
\text { some ring beams and structural } \\
\text { columns, and some nodes are } \\
\text { broken. }\end{array}$ & $\begin{array}{l}\text { There are widespread cracks in } \\
\text { the roof, some serious cracks } \\
\text { and even partial collapse. }\end{array}$ \\
\hline Collapse & Most load-bearing walls collapsed. & $\begin{array}{c}\text { Some ring beams and structural } \\
\text { columns are broken at the } \\
\text { nodes. }\end{array}$ & $\begin{array}{c}\text { The roof was severely cracked } \\
\text { and even collapsed. }\end{array}$ \\
\hline
\end{tabular}

Table 3. Classification of damage degree of stone-wood structure rural dwelling components.

\begin{tabular}{cccc}
\hline Damage level & Wall & Wooden elements & Roof \\
\hline Intact & $\begin{array}{c}\text { The walls are intact, with small cracks in } \\
\text { some cases: small diagonal cracks in the } \\
\text { corners of the doors and windows. }\end{array}$ & The wooden pillars are intact. & $\begin{array}{c}\text { The roof is intact, and some roof } \\
\text { tiles are satin. }\end{array}$ \\
\hline Minor & $\begin{array}{c}\text { There are cracks at the corners of the wall } \\
\text { and the junction of vertical and horizontal } \\
\text { walls; There are obvious cracks in } \\
\text { non-load-bearing walls, roof chimneys, and } \\
\text { parapets; } \\
\text { There are cracks in gables or door and } \\
\text { window openings. }\end{array}$ & $\begin{array}{c}\text { There is looseness at the nodes } \\
\text { of the wooden columns. }\end{array}$ & Some roof tiles slip off. \\
Moderate & $\begin{array}{c}\text { The walls have serious cracks; } \\
\text { non-load-bearing walls have many cracks } \\
\text { or are partially broken. }\end{array}$ & $\begin{array}{c}\text { Loose or slight slippage at the } \\
\text { joints of the wooden columns. }\end{array}$ & Most of the roof tiles slip off. \\
\hline Serious & $\begin{array}{c}\text { Part of the wall collapsed or severely } \\
\text { crooked. }\end{array}$ & $\begin{array}{c}\text { Some wooden pillars collapsed } \\
\text { or tilted. }\end{array}$ & Part of the roof collapsed. \\
\hline Collapse & The wall collapsed. & The wooden pillar collapsed. & $\begin{array}{c}\text { The roof was seriously } \\
\text { deformed or even collapsed. }\end{array}$ \\
\hline
\end{tabular}

Table 4. Classification of damage degree of wooden rural dwelling components.

\begin{tabular}{cccc}
\hline Damage level & Enclosure wall & Wooden columns & Roof \\
\hline Intact & $\begin{array}{c}\text { The walls are intact, with small cracks in } \\
\text { some cases: small diagonal cracks at the } \\
\text { corners of doors and windows. }\end{array}$ & The wooden pillars are intact. & $\begin{array}{c}\text { The roofs are intact, and some } \\
\text { roof tiles are satin. }\end{array}$ \\
\hline Minor & $\begin{array}{c}\text { There are cracks at the corner of the wall } \\
\text { and the junction of the vertical and } \\
\text { horizontal walls. }\end{array}$ & $\begin{array}{c}\text { There is looseness at the node of } \\
\text { the wooden column. }\end{array}$ & Some roof tiles slip off. \\
\hline Moderate & Some walls have serious cracks, and some \\
walls collapsed. & $\begin{array}{c}\text { Loose or slight slippage at the } \\
\text { joints of the wooden columns. }\end{array}$ & $\begin{array}{c}\text { The roof is deformed and most } \\
\text { of the roof tiles slip off. }\end{array}$ \\
\hline Serious & Part of the wall collapsed or severely & Some wooden pillars collapsed & The roof was deformed greatly, \\
\hline
\end{tabular}




\begin{tabular}{cccc}
\hline Damage level & Enclosure wall & Wooden columns & Roof \\
\hline collapse & crooked. & or tilted. & and part of the roof collapsed. \\
\hline & The wall collapsed. & The wooden pillar collapsed. & $\begin{array}{c}\text { The roof was seriously } \\
\text { deformed or even collapsed. }\end{array}$ \\
\hline
\end{tabular}

The states of seismic damages are divided into five levels. And the detailed classification standards for each structure type are different. The establishment of the earthquake loss matrix of buildings in rural villages requires not only a detailed classification of the loss of the structures, but also a combination of the vulnerability analysis of the structure. The seismic vulnerability analysis of the structure is an estimation and synthesis of the various damage degrees of the structure under the action of earthquake. Choosing the appropriate analysis method of vulnerability is the key to accurately evaluate the comprehensive vulnerability of structures and regional buildings. Since the seismic capacity of structure varies with the structure type, the diversity of structure types leads to the diversity of seismic capacity evaluation methods.

\section{2. vulnerability analysis methods}

Reasonable vulnerability estimation method can be used to make correct analysis of the existing structure, so as to make a relatively accurate evaluation seismic resistance ability of the structures in rural village in future earthquakes. The purpose of improving the comprehensive earthquake resistance of a city or a country could be achieved. However, the vulnerability analysis method must be based on large of historical seismic damage data. At present, the seismic damage data of buildings in the world is scarce. In the past several major earthquake disasters occurred in China, most of the buildings that were damaged or affected were buildings with weak seismic resistance ability, and they were not able to adapt to the rapid development of the demand of seismic resistance of buildings in such fast-developing time.

At present, the vulnerability analysis methods which commonly used are mainly divided into empirical analysis methods and theoretical analysis methods. The empirical analysis method requires a large amount of seismic damage data, analyses the seismic damage data and then defines the damage level, summarizes the relationship between the ground motion and the degree of damage to the structures, and estimates the existing structures which under the different intensity destruction level. The theoretical analysis rules need to refer to the relationship between seismic damage data and characteristics of structures, and calculate using seismic design code calculations or dynamic response analysis methods, then establish the relationship between structural response characteristics and ground motion intensity.

Based on the results of characteristics of structure seismic response, the earthquake damage level could be obtained. The empirical analysis method is to predict the earthquake damage of the structures according to the relationship between the earthquake damage index and the damage degree obtained from the seismic damage survey data. This method can be specifically divided into direct statistical analysis method, equivalent statistical method and experience summary method. The theoretical analysis method is to obtain the structural response through theoretical calculations, and finally to assessing the structural seismic damage degree through the relationship between the structural response and the seismic damage degree. The theoretical analysis method analyses the vulnerability of the structure, which need to select the indicators that correspond to the damage status of the structure and can reflect the seismic resistance of various types of structures. Finally, the relationship between the seismic capacity of the structure and the degree of damage is determined. Based 
on the available data, this article will use empirical methods to analyses the vulnerability of rural dwellings in China.

Since the 20th century, many destructive earthquakes have occurred in China, especially in recent decades. These earthquakes have caused huge economic losses and casualties to China. This article summarizes the earthquake damages that have great impact on rural villages among these earthquakes, and gives the proportion of rural structures with different degrees of damage during different earthquake intensities, which is the historical damage matrix (HDM). Based on the summary of HDM of structures in rural village, the damage matrix of different types structure under different intensity of 6-10 degrees is provided as a basis for estimating the seismic resistance ability of existing buildings in rural village and the possible earthquake damage in future earthquakes.

In order to quantitatively describe the vulnerability level of structures in rural village, the seismic vulnerability index (VID) is used to express as follow equation

$$
\mathrm{VID}=\frac{1}{5} \sum_{\mathrm{I}=6}^{10} \sum_{\mathrm{j}=1}^{5} P\left[D_{j} \mid I\right] r_{j}
$$

$\mathrm{P}\left[D_{j} \mid I\right]$ is structure damage matrix; $I$ is seismic intensity; $D_{j}$ is structure damage level, $j$ is destruction level $(1 \sim 5) ; r_{j}$ is loss ratio in case of $\mathrm{j}$ destruction level.

The VID of building refers to the average value of the earthquake loss rate of a certain type of building under the intensity of 6-10 degrees. The greater of the VID, the seismic resistance ability of the structures are worse. From the equation, we can see that the vulnerability index is related to the loss ratio of the structures, and it increases with the increase of the loss ratio. The loss ratio means that after a certain level of damage to the buildings, which is the ratio of the required cost to restore to original state.

The seismic vulnerability of building mainly refers to the comprehensive consideration of the degree of structural damage, and the loss ratio has a certain relationship with the current price of the buildings. This paper considers that is not appropriate to introduce the loss ratio into the vulnerability index.

The seismic vulnerability index should be a comprehensive value of the probability of damage to the same type of structure in the study area under various earthquake intensities. It should be said that the vulnerability is an inherent property of the structure, and the seismic vulnerability is the response of the structural vulnerability to the earthquake. Therefore, the seismic vulnerability index is the response of the structure to the earthquake. Although the seismic vulnerability index is calculated through the damage ratio of different damage levels of the structure under different ground motion parameters, the index and the ground motion parameters are not necessarily related to VID. Therefore, this study gives the recommended equation for VID. The equation is

$$
\mathrm{VID}=\frac{1}{5} \sum_{\mathrm{I}=6}^{10} \sum_{\mathrm{j}=1}^{5} P\left[D_{j} \mid I\right] /(6-j)
$$

$\mathrm{P}\left[D_{j} \mid I\right]$ is structure damage matrix; $I$ is seismic intensity; $D_{j}$ is structure damage level, $j$ is destruction level $(1 \sim 5)$.

It can be seen from the newly study about seismic vulnerability index. It should be said that this calculation method is relatively straightforward to operate. The damage level is divided into five levels. The boundary between the five levels is a method based on fuzzy mathematics. In the definition of the vulnerability index, the contribution of each damage level to the vulnerability 
index is different. In order to distinguish this difference in contribution rate, this paper introduced the serial earthquake damage state. Assuming that the percentage of basic integrity is $100 \%$ and the other damage levels are $0 \%$, the vulnerability index is 0.2 . Under all severity, the percentage of damage is $100 \%$, and the other damage levels are $0 \%$, then the vulnerability index is 1 . In other words, the maximum value of the vulnerability index is 1 , and the minimum value is 0.2 . The smaller number of vulnerability index, the strongest of the earthquake resistance ability of the buildings.

Based on the statistical analysis of large of earthquake damage matrices, this study has given the distribution rule of earthquake damage index and corresponding intensity. The seismic damage matrix of unknown intensity is derived from the earthquake damage matrix of existing intensity. It is assumed that the expected value and variance of the earthquake damage index between adjacent intensities are the same as the expected value and variance of the standard earthquake damage matrix. As a result, the expected value and variance of the seismic damage index under different intensities can be obtained. At the same time, the distribution of the seismic damage index under other intensities is considered to obey the beta distribution. The equation of probability density of distribution as follow:

$f_{\xi}(x, \alpha, \beta)=\left\{\begin{array}{cr}\frac{1}{B(\alpha, \beta)} x^{\alpha}(1-x)^{\beta-1} x & \in(0,1) \\ 0 & \notin(0,1)\end{array}\right.$

Where: $\alpha$ is the expectation of damage index; $\beta$ is variance the expectation of damage index.

The $\beta$ distribution corresponding to the intensity sub-seismic damage index can be determined by the following equation. Then, the transcendental probability value for each level of destruction can be obtained.

$$
P\left(x_{i} \leqslant x \leqslant x_{i+1} \mid I\right)=\int_{x_{i}}^{x_{i+1}} f(x \mid I) \mathrm{d} x
$$

Where: $I$ is earthquake intensity.

Considering of the historical seismic loss data of buildings in rural villages, the classification criteria of earthquake damage of buildings are perfected, and a database of vulnerability analysis is established. Based on the analysis of seismic vulnerability of different types of building structures, the probability distribution function of $\beta$ is used to carry out a detailed classification of historical seismic data to obtain the seismic vulnerability index of different types of rural buildings under different seismic intensity conditions.

\section{Seismic vulnerabilities of the structures in rural area}

\subsection{The characteristics of seismic damage of structure in rural village}

Seismic vulnerability analysis refers to the probability of a certain degree of damage to the structures under various intensities of earthquakes, which know as earthquake damage prediction (Mauro et al., 2003, Alex et al., 1996). The object of vulnerability analysis can assess a single structure, a city or an area. Before conducting vulnerability analysis, basic data must be available: 1) predict the ground motion or intensity of the site, such as the corresponding 50-year probability obtained from seismic hazard analysis; 2) the inherent factors of the building include structural type, number of floors, age, quality, etc; 3) predict the magnitude of the earthquake and proportion of various types of structures in the unit. 
It can be seen that the main research content of vulnerability analysis data are seismic hazard analysis data and engineering structure seismic capability analysis data. Assessing the seismic resistance ability of buildings is to analyses and evaluates the damage of the building group under different seismic intensity conditions. Generally, the results of structure vulnerability analysis can have the following two forms: the first is the vulnerability function, which means a continuous probability density function of a certain damage level under a certain intensity condition, and represents the vulnerability of the structures. The other is the seismic damage matrix, which represents the conditional probability of a certain damage level under a certain seismic intensity, which is expressed in the form of discrete quantities. This damage matrix was proposed by Ferreira et al. It was used to predict the seismic vulnerability of building structures in 1973.

The main reason lead direct economic losses are large number of buildings collapsed in the earthquake. Statistics show that the damage and loss to structures in rural village under Mw 7 earthquakes accounted for more than $60 \%-96.7 \%$ of the total direct economic loss (see Fig 1). The seismic damage of residential buildings in different areas is quite different. The geographical environment in the western region is relatively poor, and the economic level is relatively backward. The degree of seismic damage is relatively heavy. The central and eastern regions of China are densely populated, and the economy is relatively developed. The renewal period of structures in rural village is short. The quality of buildings is high, and the degree of earthquake damage is relatively light. Traditional adobe structure, Brick-concrete structure, Wooden structure and Stone structure, Brick-wood structure are prone to collapse or severe damage under earthquakes. By comparison, the seismic performance of brick-concrete structure is better. Earthquake secondary disasters are severe, especially due to the nature of the epicenter and the special terrain. Sand liquefaction, landslides, landslides, mudslides and other phenomena are common occurrence, which magnifies the earthquake effect. The impact of small and medium-sized earthquakes below $\mathrm{Mw} 5$ on rural residential buildings cannot be ignored, and even some Mw3 and Mw4 earthquakes have caused of millions USD in economic losses and casualties. The losses of private buildings caused by small and medium earthquakes are equal to the total disaster losses.

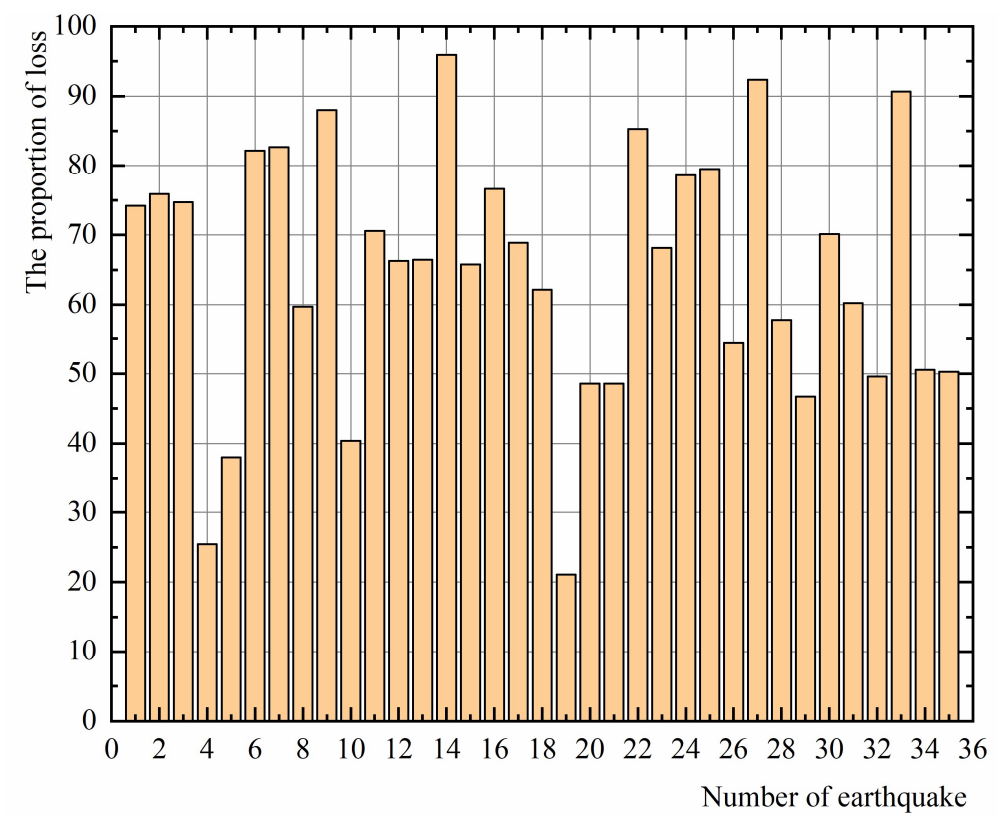


Figure 1. Proportion of loss of rural structures in earthquakes with magnitude 5 or higher in China from 2000 to 2012.

\subsection{The Types of structures in rural village}

The construction of structures in rural village of China usually carried out by local construction craftsmen according to personal economic conditions, use requirements and local traditional habits [11]. Most of structures are masonry structures with basically the same unit types, cheap construction costs, and local easy-to-use materials. The structural form and architectural style of structures in rural village have obvious regional characteristics. However, taking a broad view in China, the structures in rural village of same region are basically same. From the perspective of earthquake action, according to the vertical load-bearing elements of the rural structures, it can be divided into the following six types of structures.

1. Adobe structures (see Fig 2) generally do not have foundation treatment. The wall is built with adobe or rammed soil. Generally, adobe blocks, which use cohesive soil, are often mixed with wheat straw as tie bars during the production process. In the process of building the wall use dry soil for level, the adobe blocks are laid vertical or horizontal for the wall. Meanwhile, the structures have smaller doors and windows. Roofs are used wood, which built by two methods that are hard frame supporting and wooden roof truss. The support loads of adobe structure are vertical wooden pillars and soil wall, which is the main structural form of structures in China before 1950s. With the rapid development of the economy, the proportion of adobe structures in economically developed areas is very low. It is mainly distributed in economically backward rural areas in the west and northeast China.

2. Brick-adobe structures (see Fig 3) is the lower brick upper adobe or the outer brick inner adobe. Some of the gables are made of adobe and other walls are built with bricks. In general, the roof weight is borne by the brick-adobe wall. There are two types of roofs for brick-adobe mixed structures: one is for hard frame supporting and the other is for wooden roof trusses. Brick-adobe structure is a type of transitional structure between adobe structure and brick-wood structure. It is a result of the economic development, and the safety and reliability of rural buildings has been paid attention, but this kind of structure use two type of materials with different mechanical properties, including the connection of the two materials. However, the connection between the two materials is not reliable. From the perspective of seismic damage, the seismic capacity of the brick-adobe structure is even lower than that of the soil structure.

3. The horizontal and vertical load-bearing members of wood frame structures (see Fig 4) are wooden members. Wooden columns are used as vertical supports. Bricks, wooden boards or adobes bricks are used as retaining walls. The roofs are in the form of wooden roof trusses. This structure has four types of roofs: flat roof wooden structures. (This kind of roof truss is thick with thin columns, wooden columns are built into the retaining wall, and there is no connection between the wooden columns and the wall. There is no concealed joint between the wooden columns and the beam. There are no other diagonal braces or connections. Measures, this structural form is widely distributed throughout the country, mainly in northern regions and western regions with less rain);Slope roof wooden frame (the main beam in this type of roof truss is relatively thick, with beams of different heights on the melon pillars, sandals are placed on each melon pillar, and sandalwood is laid on the sandalwood); triangular wooden pillar wooden roof trusses (wood pillars are used vertically Load-bearing, triangular wooden roof trusses are placed in each room, wooden 
posts are connected to the roof mortise and tenon, sandalwood is placed at the nodes of the two isosceles of the triangular roof truss, and rafters are laid on the wooden rafters. This structure is mainly distributed in the east area); piercing wooden frames (each frame is supported by 3-5 wooden columns in the vertical direction, the top and middle of the wooden columns are connected by piercings, and the short columns in the upper part of the frame are also connected by piercings and wooden members. It is relatively rich, and generally consists of tenon-joint, dovetail connection, butt joint, etc. This type of structure is mainly distributed in southwest China.

4. Stone structures (see Fig 5) is vertically supported by stone walls. The stones were often built with silty clay or cement mortar. This type of structure is restricted by stones and is mainly distributed in mountainous areas such as the western and southeast coasts of China.

5. Brick-wood structures (see Fig 6) are currently the most common structural form used in rural village of China. The main supporting structure of a brick-wood structure is masonry structure or wooden truss structure [12-18]. The roofs of brick and wood structure are wooden roofs, which have four types such as double-slope roofs, single-slope roofs, and flat roofs. Most of them are in the form of hard frame supporting. The brick walls of the structures are mainly used as vertical load-bearing members. Masonry materials generally include mud, slag mortar, cement mortar. The wall varies significantly from north to south. The temperature in the northeast is relatively low. In order to keep warm, the thickness of the wall is $49 \mathrm{~cm}$. The thickness of walls is $37 \mathrm{~cm}$ mainly distributed in the central and western regions of China.

6. Brick-concrete structure (see Fig 7) is the most commonly used structural form in rural villages of China in recently years. Vertical brick walls are used to load-bearing walls. The brick walls are built with cement mortar. The form of roof has precast slab or reinforced concrete cast-in-place. Due to the unreliable connection between the prefabricated slabs and the prefabricated slabs and the wall, the seismic capacity of the two brick-concrete structures is quite differment.

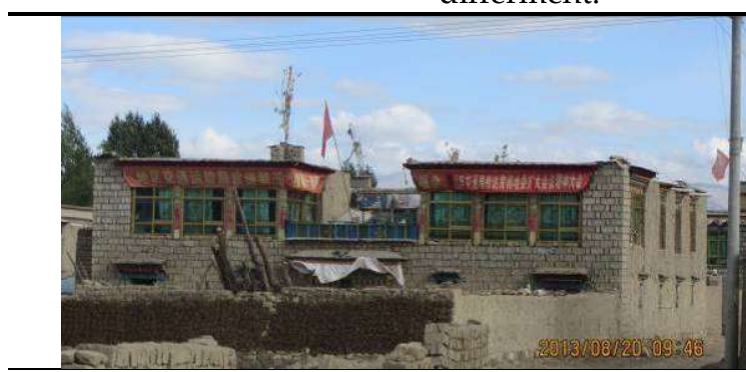

Figure 2. adobe structure

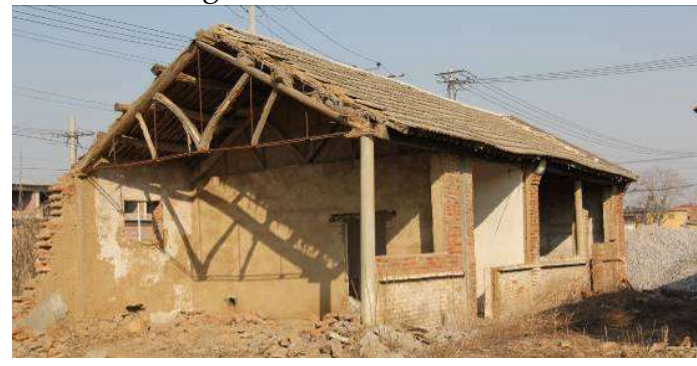

Figure 4. Wooden frame structure

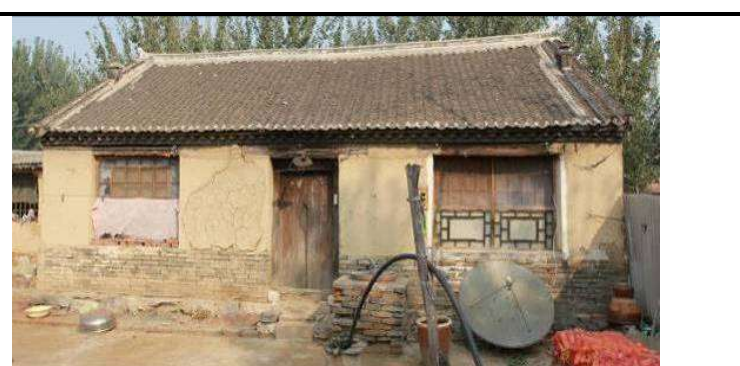

Figure 3. Brick-adobe structure

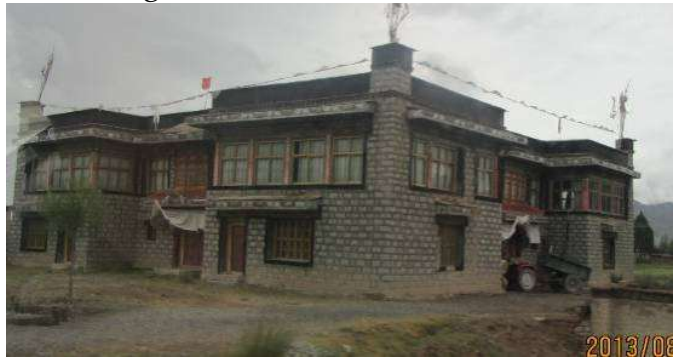

Figure 5. Stone structure 


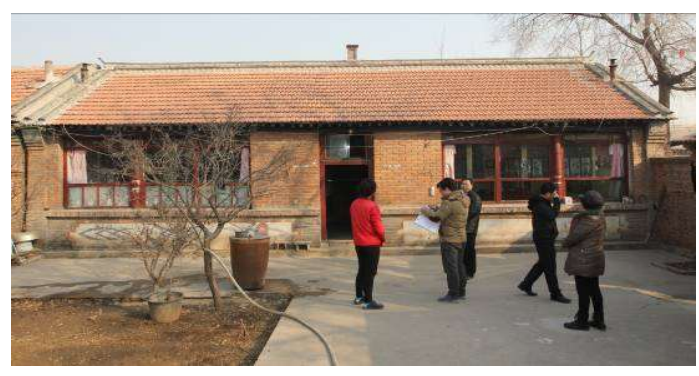

Figure 6. Brick-wood structure

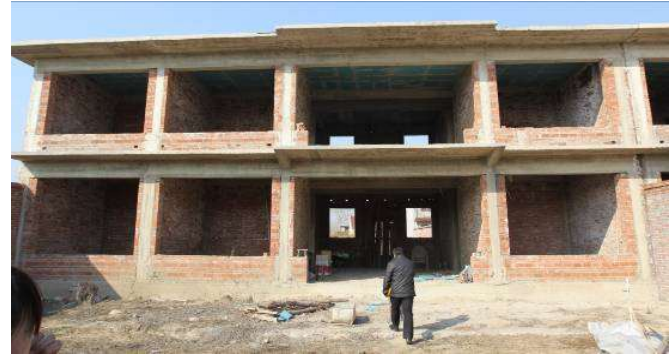

Figure 7. Brick-concrete structure

\subsection{The characteristic of earthquake damage}

Historical seismic disaster data is the basis of buildings vulnerability index and earthquake disaster matrix. This paper summarizes the damage status of different types of buildings in historical earthquakes to guide the evaluation of the seismic properties of existing buildings. Based on the historical seismic disaster data, the seismic disaster matrix is established, and the building vulnerability in the affected area is evaluated to verify whether the existing vulnerability analysis method is accurate.

The earthquake damage in Minxian County was relatively light, and a few structures showed slight cracks. The structures on the mountain in Meichuan Town and Hetuo Town were seriously damaged by the earthquake. The adobe structures are mostly partially collapsed or totally collapsed. The main reason was that the adobe wall was used as a dry wall or used as a base. The adobe wall has very low strength resistant ability. The roof is connected to the top of the wall as simple shelving, without tie-in measures. The connection between the adobe wall junctions is poor, and the gable wall is easy to flash out under strong earthquakes. The wooden roof is thicker. The soil and grass mixed surface layer, resulting in a heavy roof. Most rural structures with wooden framed soil walls collapsed as gables, a small number were collapsed with multi-sided earth walls, and a few were severely inclined, but the wooden frame basically did not fall. The main reason is that there is no tie between the soil wall and the wooden frame, and the external wall is easy to flash out; the material laid on the wooden roof is too heavy. As long as the anti-seismic structure measures are in place, the brick wall load-bearing wooden roof farm structures will perform well under the action of the earthquake and its structure is basically intact. The single-storey farm structures with the wooden frame and the wooden roof of the brick wall is basically intact, only cracks appear between the front walls and the wooden pillars on both sides of the structures; the single-storey farm structures with the brick wall and the wooden roof has ring beams but no structural columns. The wall was severely damaged and the cracks were wide. Brick-concrete structures are mainly concentrated in the township government.

Table 5. The structure damage matrix in Mw 6.6 earthquake in Luxian County.

\begin{tabular}{ccccccc}
\hline Intensity & Structural type & Collapse & Serious & Moderate & Minor & Intact \\
\hline \multirow{3}{*}{ Mw8 } & adobe structure & 35.2 & 39.7 & 16.4 & 5.7 & 2.7 \\
& Brick-wood structure & 14.2 & 23.9 & 28.1 & 25.9 & 7.9 \\
& Brick-concrete structure & 2.2 & 4.8 & 11.6 & 36.4 & 45.0 \\
\multirow{3}{*}{ Mw7 } & adobe structure & 14.0 & 21.3 & 25.5 & 23.6 & 15.6 \\
& Brick-wood structure & 2.9 & 7.7 & 18.9 & 41.8 & 28.7 \\
& Brick-concrete structure & 1.2 & 5.1 & 14.2 & 27.7 & 51.8 \\
\hline
\end{tabular}




\begin{tabular}{lcccccc}
\hline \multirow{3}{*}{ Mw6 } & adobe structure & 3.3 & 6.0 & 10.5 & 19.4 & 60.8 \\
& Brick-wood structure & 0.6 & 1.2 & 5.3 & 23.9 & 69.0 \\
& Brick-concrete structure & 0.0 & 0.0 & 0.7 & 3.7 & 95.6 \\
\hline
\end{tabular}

The structures in Uyghur region are mainly divided into adobe structures and brick-timber structures. The adobe structures include dry earth walls or adobe masonry walls. The adobe structures were built earlier, and more than $90 \%$ of them were built by the building owner. The local loess has heavier sand content and poor wall adhesion. Most of the brick-wood structures were built in 2011, and it is also the main structural form for the implementation of the project to enrich the people in Uyghur region. The foundations of the brick-wood structure farm structures mostly use sand and stone cushions. The foundation is made of concrete ground ring beams, the roof is set with concrete roof ring beams, and the roof truss is in the form of a wooden roof. In the past 20 years, the historical earthquake damage to rural residences in Uyghur region shows that when the earthquake intensity of civil structure structures is 6 degrees, the proportion of civil structure structures above the damage level accounted for $60.3 \%$, and the proportion of damage accounted for $13.3 \%, 7$ degrees. At the time, the percentage of damage above the level even reached $81.2 \%$, and the percentage of damage was $34.1 \%$. Obviously, the earthquake resistance of civil-timbered structures is relatively poor and the earthquake damage is heavy. For brick-timbered structures, when the earthquake intensity is 6 degrees, the proportion of damage above the medium level is $22.05 \%$, and the proportion of damage is $0.67 \%$, and when the earthquake intensity is 7 degrees, the proportion of damage above the medium level is $34.38 \%$, and the proportion of damage is $0.85 \%$.

Table 6. the seismic damage matrix under Mw7 earthquake (\%).

\begin{tabular}{cccccc}
\hline Structural type & Collapse & Serious & Moderate & Minor & Intact \\
\hline Brick-wood structure & 0.0 & 5.0 & 29.0 & 44.0 & 23.0 \\
cave structure & 12.0 & 38.0 & 29.0 & 18.0 & 3.0 \\
Adobe structure & 2.0 & 21.0 & 33.0 & 23.0 & 21.0 \\
\hline
\end{tabular}

Table 7. the seismic damage matrix under Mw6 earthquake (\%).

\begin{tabular}{cccccc}
\hline Structural type & Collapse & Serious & Moderate & Minor & Intact \\
\hline Brick-wood structure & 0.0 & 0.0 & 15.0 & 50.0 & 35.0 \\
Cave structure & 0.0 & 10.0 & 28.0 & 30.0 & 31.0 \\
Adobe structure & 0.0 & 2.0 & 24.0 & 40.0 & 35.0 \\
\hline
\end{tabular}

\section{Data analysis}

In order to obtain the seismic damage matrix of structures in rural villages, this study analyzed the historical seismic damage matrix of buildings in rural village of China, especially the seismic damage matrix of structures in recent years. The study conducted statistics on earthquakes with damage matrix in recent years. Table 8 shows the statistics of some earthquakes in China from 1996 to 2013. Special research and analysis were carried out the seismic damage matrix with corresponding intensity (Table 9-11).

Table 8. History earthquakes in China from 1996 to 2013.

\begin{tabular}{cccc}
\hline Earthquake number & Date & Location & magnitude \\
\hline 1 & 2005.11 .26 & Jiujiang-Ruichang & 5.7 \\
2 & 2003.10 .16 & Dayao, Yunnan & 6.1 \\
3 & 2003.2 .24 & Uyghur region Bachu-Jiashi & 6.8 \\
4 & 1998.11 .19 & Ninglang, Yunnan & 6.2
\end{tabular}




\begin{tabular}{cccc}
\hline Earthquake number & Date & Location & magnitude \\
\hline 5 & 1998.1 .10 & Zhangbei, Hebei & 6.2 \\
6 & 1996.5 .3 & West Inner Mongolia Baotou & 6.4 \\
7 & 1996.2 .3 & Yun nam Li jiang & 7.0 \\
8 & 2013.7 .22 & Ganxian County & 6.6 \\
\hline
\end{tabular}

The actual earthquake damage matrix is based on the buildings damage survey statistics of a specific earthquake in rural village. It is affected by some special conditions and may not be universally representative. Based on this, this study selects the earthquake damage matrix of the rural buildings formed during the earthquake and supplemented with the earthquake damage matrix of 6 to 10 degrees.

Table 9. Earthquake damage matrix for brick-wood structures.

\begin{tabular}{|c|c|c|c|c|c|c|}
\hline \multirow{2}{*}{$\begin{array}{c}\text { Earthquake } \\
\text { number }\end{array}$} & \multirow{2}{*}{ Seismic intensity } & \multicolumn{5}{|c|}{ Destruction level (\%) } \\
\hline & & intact & minor & moderate & Serious & Collapse \\
\hline \multirow{5}{*}{2} & 6 & 76.55 & 17.70 & 5.75 & 0 & 0 \\
\hline & 7 & 35.35 & 32.93 & 31.72 & 0 & 0 \\
\hline & 8 & 12.24 & 40.82 & 25.71 & 16.73 & 4.50 \\
\hline & 9 & 2.96 & 12.33 & 23.01 & 37.30 & 24.40 \\
\hline & 10 & 0.00 & 0.00 & 24.27 & 38.88 & 36.85 \\
\hline \multirow{5}{*}{3} & 6 & 66.01 & 26.54 & 6.70 & 0.75 & 0.00 \\
\hline & 7 & 47.2 & 28.1 & 19.2 & 5.5 & 0 \\
\hline & 8 & 10 & 25 & 40 & 25 & 0 \\
\hline & 9 & 0 & 0 & 30 & 50 & 20 \\
\hline & 10 & 0.00 & 0.00 & 3.47 & 59.43 & 37.10 \\
\hline \multirow{5}{*}{4} & 6 & 68.64 & 18.46 & 10.27 & 2.63 & 0 \\
\hline & 7 & 19.90 & 33.35 & 32.80 & 13.95 & 0 \\
\hline & 8 & 0 & 12.50 & 50.00 & 37.50 & 0 \\
\hline & 9 & 0.24 & 3.40 & 13.46 & 39.22 & 43.68 \\
\hline & 10 & 0.00 & 0.00 & 19.28 & 35.06 & 45.65 \\
\hline \multirow{5}{*}{5} & 6 & 16 & 31 & 40 & 7 & 6 \\
\hline & 7 & 5 & 24 & 45 & 22 & 4 \\
\hline & 8 & 0 & 5 & 10 & 20 & 65 \\
\hline & 9 & 0.00 & 0.00 & 14.95 & 16.56 & 68.49 \\
\hline & 10 & 0.00 & 0.00 & 11.13 & 17.83 & 71.04 \\
\hline \multirow{5}{*}{7} & 6 & 73.0 & 19.0 & 8.0 & 0 & 0 \\
\hline & 7 & 39 & 37 & 16 & 8 & 0 \\
\hline & 8 & 10 & 40 & 35 & 15 & 0 \\
\hline & 9 & 0 & 14 & 31 & 42 & 13 \\
\hline & 10 & 0.00 & 0.00 & 13.99 & 22.41 & 63.60 \\
\hline \multirow{5}{*}{8} & 6 & 69.0 & 23.9 & 5.3 & 1.2 & 0.6 \\
\hline & 7 & 28.7 & 41.8 & 18.9 & 7.7 & 2.9 \\
\hline & 8 & 7.9 & 25.9 & 28.1 & 23.9 & 14.2 \\
\hline & 9 & 5.19 & 9.73 & 14.03 & 25.86 & 45.19 \\
\hline & 10 & 0.00 & 0.00 & 16.51 & 26.46 & 57.03 \\
\hline
\end{tabular}

Table 10. Earthquake damage matrix for adobe structure.

\begin{tabular}{ccccccc}
\hline \multirow{2}{*}{$\begin{array}{c}\text { Earthquake } \\
\text { number }\end{array}$} & Seismic intensity & \multicolumn{5}{c}{ Destruction level (\%) } \\
\cline { 3 - 7 } & 2 & intact & minor & moderate & Serious & Collapse \\
\cline { 3 - 8 } & 7 & 72.33 & 21.83 & 5.85 & 0 & 0 \\
\hline
\end{tabular}




\begin{tabular}{|c|c|c|c|c|c|c|}
\hline \multirow{5}{*}{$\begin{array}{c}\text { Earthquake } \\
\text { number }\end{array}$} & \multirow{2}{*}{ Seismic intensity } & \multicolumn{5}{|c|}{ Destruction level (\%) } \\
\hline & & intact & minor & moderate & Serious & Collapse \\
\hline & 8 & 5.41 & 32.73 & 26.13 & 21.62 & 14.11 \\
\hline & 9 & 4.01 & 17.46 & 24.58 & 33.47 & 20.49 \\
\hline & 10 & 0.00 & 0.00 & 30.05 & 40.23 & 29.72 \\
\hline \multirow{5}{*}{3} & 6 & 65.80 & 21.74 & 12.46 & 0.00 & 0.00 \\
\hline & 7 & 41.04 & 25.22 & 17.39 & 12.94 & 3.41 \\
\hline & 8 & 1.55 & 11.01 & 17.48 & 27.2 & 42.76 \\
\hline & 9 & 0 & 0 & 0 & 0 & 100 \\
\hline & 10 & 0 & 0 & 0 & 0 & 100 \\
\hline \multirow{5}{*}{4} & 6 & 64.63 & 25.17 & 9.51 & 0.69 & 0 \\
\hline & 7 & 31.99 & 37.99 & 20.58 & 8.74 & 0.70 \\
\hline & 8 & 0 & 19.14 & 54.03 & 25.26 & 1.58 \\
\hline & 9 & 0.00 & 10.84 & 33.52 & 41.54 & 14.11 \\
\hline & 10 & 0.00 & 14.66 & 27.16 & 25.09 & 33.08 \\
\hline \multirow{5}{*}{6} & 6 & 52.86 & 28.11 & 13.34 & 4.13 & 1.56 \\
\hline & 7 & 29.59 & 33.58 & 23.47 & 11.30 & 2.06 \\
\hline & 8 & 5.09 & 6.36 & 31.16 & 39.46 & 17.93 \\
\hline & 9 & 0.00 & 9.22 & 19.21 & 36.89 & 34.68 \\
\hline & 10 & 0.00 & 0.00 & 22.18 & 37.01 & 40.81 \\
\hline \multirow{5}{*}{7} & 6 & 63.6 & 25.5 & 10.1 & 0.8 & 0 \\
\hline & 7 & 36.8 & 28.8 & 25.3 & 9.1 & 0 \\
\hline & 8 & 5.9 & 36.8 & 46.8 & 7.3 & 3.1 \\
\hline & 9 & 0 & 4.3 & 28.0 & 52.6 & 15.2 \\
\hline & 10 & 0.00 & 0.00 & 23.32 & 41.43 & 35.25 \\
\hline \multirow{5}{*}{8} & 6 & 60.8 & 19.4 & 10.5 & 6.0 & 3.3 \\
\hline & 7 & 15.6 & 23.6 & 25.5 & 21.3 & 14.0 \\
\hline & 8 & 2.7 & 5.7 & 16.4 & 39.7 & 35.5 \\
\hline & 9 & 0 & 4.52 & 15.33 & 33.83 & 46.31 \\
\hline & 10 & 0 & 0 & 11.54 & 34.62 & 53.85 \\
\hline
\end{tabular}

Table 11. Earthquake damage matrix of brick-concrete structure.

\begin{tabular}{|c|c|c|c|c|c|c|}
\hline \multirow{2}{*}{$\begin{array}{c}\text { Earthquake } \\
\text { number }\end{array}$} & \multirow{2}{*}{ Seismic intensity } & \multicolumn{5}{|c|}{ Destruction level (\%) } \\
\hline & & intact & minor & moderate & Serious & Collapse \\
\hline \multirow{5}{*}{1} & 6 & 75.30 & 0 & 21.35 & 0 & 3.35 \\
\hline & 7 & 51.97 & 0 & 39.93 & 0 & 8.10 \\
\hline & 8 & 25.14 & 0 & 26.22 & 0 & 48.64 \\
\hline & 9 & 23.10 & 11.42 & 10.19 & 15.69 & 39.61 \\
\hline & 10 & 0.00 & 31.66 & 14.37 & 15.34 & 38.63 \\
\hline \multirow{5}{*}{3} & 6 & 57.87 & 40.58 & 1.54 & 0.00 & 0.00 \\
\hline & 7 & 58.5 & 30.2 & 7.6 & 3.7 & 0 \\
\hline & 8 & 25.5 & 34.5 & 27.5 & 12 & 0.5 \\
\hline & 9 & 25.5 & 17 & 20.6 & 34.8 & 2.1 \\
\hline & 10 & 1.69 & 10.93 & 24.82 & 41.38 & 21.17 \\
\hline \multirow{5}{*}{7} & 6 & 77.0 & 20.0 & 3.0 & 0 & 0 \\
\hline & 7 & 62.0 & 25.0 & 12.0 & 1.0 & 0 \\
\hline & 8 & 19.0 & 33.7 & 36.4 & 8.7 & 2.2 \\
\hline & 9 & 16.8 & 19.6 & 14.5 & 38.1 & 11.0 \\
\hline & 10 & 2.40 & 8.99 & 17.15 & 33.21 & 38.25 \\
\hline 8 & 6 & 95.6 & 3.7 & 0.7 & 0.0 & 0.0 \\
\hline
\end{tabular}




\begin{tabular}{ccccccc}
\hline \multirow{2}{*}{$\begin{array}{c}\text { Earthquake } \\
\text { number }\end{array}$} & Seismic intensity & \multicolumn{5}{c}{ Destruction level (\%) } \\
\cline { 2 - 7 } & 7 & intact & minor & moderate & Serious & Collapse \\
\cline { 2 - 7 } & 51.8 & 27.7 & 14.2 & 5.1 & 1.2 \\
\cline { 2 - 7 } & 9 & 16.0 & 36.4 & 11.6 & 4.8 & 2.2 \\
\cline { 2 - 7 } & 10 & 0.41 & 30.31 & 29.52 & 20.64 & 3.13 \\
\hline
\end{tabular}

Based on the research on the structural types and characteristics of structures in rural village, this study analyses the vulnerability of buildings under typical earthquakes in China from 1996 to 2013, the results are as follows: earthquake damage matrix for buildings in rural village; the buildings with different structure types; characteristics of earthquake damages; reasons for severe damage to structures. On the basis of these theories, earthquake damage matrix of the buildings was improved, and the vulnerability index of typical structures in rural villages under earthquakes was given.

According to the actual construction of dwellings in rural villages, the dwellings are divided into six structural types, which are studied from the structural elements, structural characteristics and weak points of seismic resistance of the dwellings. The earthquake damage shows that there are many dwellings damaged, the casualties and losses are also high. This study analyzes the earthquake cases of typical dwellings in recent years. Therefore, this study focuses on the analysis of the damage characteristics and the damage mechanism of structures during the earthquake.

Regarding the characterization of structural vulnerability, this paper gives a new definition and corresponding formula of seismic vulnerability index based on the vulnerability index proposed by Asteris et al. (2014). The new formula is only related to the vulnerability index, which shows that different damage levels have different contributions to vulnerability. Finally, based on the earthquake damage matrix, the vulnerability index of dwellings with brick-wood structure, adobe structure, and brick-concrete structure are given.

\section{Results}

According to the definition of the vulnerability index in this study, the vulnerability index of different structure types in each earthquake was calculated. The vulnerability index can indicate the difficulty of the structure under earthquake action. The vulnerability index of buildings with brick-concrete structure is the highest, the vulnerability index of buildings in rural village with brick-wood structure is the middle, and the vulnerability index of building with adobe structure is the smallest.

The vulnerability index can be used to evaluate the damage performance of the same type structure in different earthquakes. For brick-wood structures, the vulnerability index is between $0.40-0.48$, except for the brick-wood structure in Zhangbei earthquake, which is 0.63 . It can be seen from Table 12 that the maximum seismic vulnerability index of brick-wood structures under the earthquake No. 17 Zhangbei earthquake is 0.63 . The minimum seismic vulnerability index of brick-wood structures under the earthquake No. 13 Dayao earthquake is 0.4 . The main cause of the low vulnerability index is the low compressive strength of the mortar of brick-wood structures and the poor shear resistance of the wall.

As can be seen from Table 13-14, the geographical distribution of China can be divided into two categories: the first category has vulnerability value of 0.39-0.47, mainly distributed in Yunnan and Inner Mongolia; the second category has a vulnerability value of 0.55 to 0.64 , mainly distributed in Gansu 
and Uyghur region. The seismic capacity of civil structures in different regions is quite different.

The brick-concrete structure minimum vulnerability index of the earthquake No. 20 in Ganxian was 0.31, it's indicates that the brick-concrete structure in Jianxian, Gansu had the best seismic resistance among the earthquakes; Jiujiang - Ruichang has the maximum earthquake vulnerability index, which is 0.47 , it's indicates that the brick-concrete structure rural building in Jiangxi Province has the worst seismic resistance.

Table 12. Vulnerability index of brick-wood structured.

\begin{tabular}{clc}
\hline Earthquake number & Structure type & Vulnerability Index \\
\hline 13 & Brick-wood structure & 0.40 \\
14 & Brick-wood structure & 0.41 \\
16 & Brick-wood structure & 0.46 \\
17 & Brick-wood structure & 0.63 \\
19 & Brick-wood structure & 0.41 \\
20 & Brick-wood structure & 0.48 \\
\hline
\end{tabular}

Table 13. Vulnerability Index of soil structure.

\begin{tabular}{ccc}
\hline Earthquake number & Structure type & Vulnerability Index \\
\hline 13 & soil structure & 0.40 \\
14 & soil structure & 0.64 \\
16 & soil structure & 0.39 \\
18 & soil structure & 0.47 \\
19 & soil structure & 0.40 \\
20 & soil structure & 0.55 \\
\hline
\end{tabular}

Table 14. Vulnerability Index of Brick-concrete structure.

\begin{tabular}{clc}
\hline Earthquake number & Structure type & Vulnerability Index \\
\hline 1 & Brick-concrete structure & 0.47 \\
14 & Brick-concrete structure & 0.33 \\
19 & Brick-concrete structure & 0.36 \\
20 & Brick-concrete structure & 0.31 \\
\hline
\end{tabular}

\section{Conclusion}

Based on the research on the structural types and structural characteristics of structures in rural village of China, this study analyses the vulnerability of structures in rural buildings under typical earthquakes in China from 1996 to 2013. The results are as follows: earthquake damage matrix for buildings; the buildings with different structure types; Characteristics of earthquake damages; Reasons for severe damage to farm structures. On the basis of these theories, earthquake damage matrix of the rural buildings was improved, and the vulnerability index of typical rural structures under earthquakes in China was given.

According to the actual construction of dwellings in rural village of China, the country's dwellings are divided into six structural types, which are studied from the structural elements, structural characteristics and weak points of seismic resistance of the dwellings. The earthquake damage shows that there are many structures damaged. The casualties and losses are also high. This study analyzes the earthquake cases of typical rural dwellings in recent years. Therefore, this study focuses on the analysis of the damage characteristics and the damage mechanism of structures during the earthquake. 
Regarding the characterization of structural vulnerability, this paper gives a new definition and corresponding equation of seismic vulnerability index. The new equation is only related to the vulnerability matrix, which shows that different damage levels have different contributions to vulnerability. Finally, based on the earthquake damage matrix, the vulnerability index of dwellings with brick-wood structure, civil structures, and brick-concrete structure, are given.

Acknowledgments: The authors extend thanks to China Science and Nature Foundation (41772123), Tianjin Science and Technology Major Project (18ZXAQSF00110), China Earthquake Science and Technology Spark Project (XH18005) fund support.

\section{References}

Yao, X. Q., Sun, B. T., Chen, Y. K., Yang, X. L. (2017). Study on distribution of seismic capacity of Tianjin rural residence. Building structure, 2017, Vol. 47, S1, 578-582. (in Chinese).

Polat, G., Randolph, L. (2004). The earthquake resistance of traditional timber and masonry dwellings in Turkey. 13th World Conference on Earthquake Engineering Vancouver, B.C., Canada August 1-6, 2004 , Paper No. 2297.

Güçhan, N. Ş. (2007). Observations on earthquake resistance of traditional timber-framed structures in Turkey. Building and Environment Volume 42, Issue 2, February 2007, Pages 840-851. doi: https://doi.org/10.1016/j.buildenv.2005.09.027

Yao, X. Q., Sun, B. T., Chen, Y. K., Yang, X. L., Cao, J. Q. (2019). Investigation and analysis on seismic performance of rural residences in Tianjin. Building structure, 2019, Vol. 49, No. 16, 578-582. (in Chinese).

Yao, X. Q., Sun, B. T., Liu, F., Chen, Y. K., Yang, X. L. (2017). Study on distribution of seismic capacity of Tianjin rural residence. Journal of natural disasters, Vol. 26 No. 6, 31-38. (in Chinese).

Yao, X. Q., Sun, B. T., Liu, F., Cao, J. Q. (2020). Research on seismic capacity of brick-wood structure farmhouse based on modal test in a certain area of North China. Earthquake engineering and engineering dynamics, Vol. 40 No. 4, 164-172. (in Chinese)

Yao, X. Q., Sun, B. T., Chen, Y. K., Yang, X. L. (2018). Elasto-plastic finite element analysis of typical brick-wood rural buildings under ground motions. China earthquake engineering journal, 2018, 40(1): 32-40. Doi: 10. 3969/ j. issn. 1000-0844. 2018. 01 .032.

Kenneth, A., Franch, G., Gian, M., Morbelli, G., Maximiliano, A., Inostroza, A., Gori, R. E. (2008). A seismic vulnerability index for confined masonry shear wall buildings and a relationship with the damage. Engineering Structure. 2008; 10(30): 2605-2612.

Lourenco, P. B., Roque, J. A. (2006). Simplified indexes for the seismic vulnerability of ancient masonry buildings. Construct. Build. Mater. 2006; 4(20): 200-208.

Lourenco, P. B., Oliveira, D. V., Leite, J. C., Ingham, J. M., Modena, C., Da Porto, F. (2013). Simplified indexes for the seismic assessment of masonry buildings: International database and validation. Engineering failure analysis. 2013; 1(34): 585-605.

Milutinovic, Z. V., Trendafiloski, G. S. (2003). An advanced approach to earthquake risks scenarios with applications to different European towns. WP4: Vulnerability of Current Buildings Risk-UE 2003, Greece, 2003.

National Institute of Building Sciences. Hazards risk assessment program. Washington, DC, 1997

OYO Corporation. RADIUS methodology. IDNDR, 1999.

Yousfi, N., \& Bensaibi, M. (2018). Weighting Assessment of Vulnerability Index Parameters for Reinforced Masonry Structures. Structural Engineering International, 27(1), 79-87. doi:10.2749/101686617x14676303589435

Votsis, R. A., Kyriakides, N., Chrysostomou, C. Z., Tantele, E., \& Demetriou, T. (2012). Ambient vibration testing of two masonry monuments in Cyprus. Soil Dynamics and Earthquake Engineering, 43, 58-68. doi:10.1016/j.soildyn.2012.07.015 
Romis, F., Caprili, S., Salvatore, W., Ferreira, T. M., \& Lourenço, P. B. (2021). An Improved Seismic Vulnerability Assessment Approach for Historical Urban Centres: The Case Study of Campi Alto di Norcia, Italy. Applied Sciences, 11(2). doi:10.3390/app11020849

Şahin Güçhan, N. (2007). Observations on earthquake resistance of traditional timber-framed houses in Turkey. Building and Environment, 42(2), 840-851. doi:10.1016/j.buildenv.2005.09.027

Vettore, M., Donà, M., Carpanese, P., Follador, V., da Porto, F., \& Valluzzi, M. R. (2020). A Multilevel Procedure at Urban Scale to Assess the Vulnerability and the Exposure of Residential Masonry Buildings: The Case Study of Pordenone, Northeast Italy. Heritage, 3(4), 1433-1468. doi:10.3390/heritage3040080

Preciado, A., Ramirez-Gaytan, A., Santos, J. C., \& Rodriguez, O. (2020). Seismic vulnerability assessment and reduction at a territorial scale on masonry and adobe housing by rapid vulnerability indicators: The case of Tlajomulco, Mexico. International Journal of Disaster Risk Reduction, 44. doi:10.1016/j.ijdrr.2019.101425

Li, S.-Q., \& Chen, Y.-S. (2020). Analysis of the probability matrix model for the seismic damage vulnerability of empirical structures. Natural Hazards, 104(1), 705-730. doi:10.1007/s11069-020-04187-2

Gautam, D., \& Chaulagain, H. (2016). Structural performance and associated lessons to be learned from world earthquakes in Nepal after 25 April 2015 (MW 7.8) Gorkha earthquake. Engineering Failure Analysis, 68, 222-243. doi:10.1016/j.engfailanal.2016.06.002

Lourenço, P. B. (2002). Computations on historic masonry structures. Progress in Structural Engineering and Materials, 4(3), 301-319. doi:10.1002/pse.120

Pakdamar, F., Kara, F. I., Eryilmaz, Y., \& Yesilyurt, A. (2019). Seismic risk assessment using updated hazard and building inventory data. Gradevinar, 71(5), 375-387. doi:10.14256/jce.2329.2018

China Earthquake Administration. (1998). Outline and Technical Guidelines for Earthquake Site Work. Earthquake Press, 1998, 05. (in Chinese).

Mauro, D., Angelo, M., Maria, M., Marco, V. (2003). Earthquake damage scenarios of the building stock of potenza (southern Italy) including site effects. Bulletin of Earthquake Engineering volume 1, pages115-140. Doi:http:// 10.1023/A:1024809511362.

Alex, H., Fabricio, Y., JoséA, C. (1996). Damage scenarios simulation for seismic risk assessment in urban zones. Earthquake Spectra, Volume: 12 issue: 3, page(s): 371-394 Issue published: August 1, 1996. Doi: https://doi.org/10.1193/1.1585889

Ferreira, T. M., Maio, R., \& Vicente, R. (2016). Seismic vulnerability assessment of the old city centre of Horta, Azores: calibration and application of a seismic vulnerability index method. Bulletin of Earthquake Engineering, 15(7), 2879-2899. doi:10.1007/s10518-016-0071-9

Asteris, P. G., Chronopoulos, M. P., Chrysostomou, C. Z., Varum, H., Plevris, V., Kyriakides, N., \& Silva, V. (2014). Seismic vulnerability assessment of historical masonry structural systems. Engineering Structures, 62-63, 118-134. doi:10.1016/j.engstruct.2014.01.031 